\title{
Diversity of Pods and Beans of Twelve Cocoa Clones (Theobroma cacao L.) in Rainy and Dry Seasons
}

\author{
Adinda Wuriandani ${ }^{* *}$, Agung Wahyu Susilo ${ }^{2)}$, Suyadi Mitrowiardjo ${ }^{1)}$, \\ Bayu Setyawan ${ }^{2)}$, and Indah Anita Sari ${ }^{2)}$ \\ ${ }^{1)}$ Gadjah Mada University, Bulaksumur, Yogyakarta \\ ${ }^{2}$ Indonesian Coffee and Cocoa Research Institute, Jl. PB. Sudirman 90, Jember \\ ${ }^{*}$ Corresponding author: adindawuriandani@gmail.com \\ Received: 6 October 2017 / Accepted: 12 December 2018
}

\begin{abstract}
Cocoa is a sensitive plant to availability of soil water. The availability of water affects the formation of cocoa pods and beans. The aim of this research was to determine the genetic diversity and the influence of season on the diversity of cocoa beans quality as well as determining the pattern of genotype and season interaction on the quality of physical physiology of cacao beans. The research was conducted in Kaliwining Experimental Station, Indonesian Coffee and Cocoa Research Institute, Jember during dry season (2015) and rainy season (2016). This study used a complete randomized block design $2 \times 12$ factorial and three replicates as blocks. The first factor was the season consisting of two levels namely, dry season and rainy season. The second factor was cocoa clones, TSH 858, KW 084, KEE 2, Sulawesi 1, Sulawesi 2, BAL 209, KW 215, JTC 5A, JTC 5B, KC 2, KKM 22, and KJ 2. Observation variables included pod diameter, pod length, pod weight, dry bean weight, number of good beans/pod, number of empty beans/pod, number of beans, and number of pods/tree/season. Data was analyzed using ANOVA fixed factor. The bean dry weight characteristics possesed a low genetic diversity $(0.27 \%)$ whereas the physical quality character of other beans, i.e bean count had moderate genetic diversity (14.20\%). Meanwhile, the real difference was shown on the dry weight of bean characteristics. The best dry bean weight was observed during the dry season. Clones KW 215 and Sulawesi 1 in the dry season was categorized in grade A, while the lowest quality JTC 5A with grade D. The interaction of genotype (clone) with the environment (season) resulted in a significant effect on pod diameter character, pod weight, bean count, dry bean weight, and number of pods/tree. Based on the biplot AMMI graph it was known that the TSH 858 clone showed genetic stability in bean count character. As for the character of the number of pods/tree, clones KKM 22, BAL 209, and KW 084 had the stability of the number of pods in rainy and dry seasons. Clones KJ 2 and Sulawesi 2 showed season-specific in the dry season for the number of pods/tree characters.
\end{abstract}

Keywords: AMMI, analysis of variance, cross-sectional analysis, physical quality of cocoa beans

\section{INTRODUCTION}

Cocoa is one of the leading commodities in Indonesia. In the last two decades, cocoa sector continues to experience significant growth. The national cocoa production also continues to increase along with area increase (Prawoto, 2008). Indonesia is the third largest 
cocoa producer in the world at cocoa processing capacity 800,000 tons/year. According to Plantation Statistics data from 2014 to 2016, cocoa production in 2015 reached 661,243 tons (Ditjenbun, 2015). Ideal cocoa production target wasn't realized due to the use of poor planting materials, less optimal cultivation technology, plant age, as well as pest and disease problems (Wahyudi \& Rahardjo, 2008).

Cocoa planting materials will always be needed to support optimal cocoa production. The fulfillment of planting materials will certainly be constrained by constantly changing environmental factors including seasonal changes. Currently, Indonesia is facing a natural phenomenon that affects agricultural production, including plantations. The natural phenomenon is El Nino and La Nina. El Nino delays the beginning of rainy season. El Nino affected Indonesia in March 2015 and peaked in December 2015. La Nina's natural phenomenon is the opposite phase of El Nino which will lead to an increase in tidal water, heavy rain and storms (ACAPS, 2016).

Production declines occur during drought and it affects the following year. Cacao plants are known requiring small amount water to grow and are available throughout the year (Obatolu et al., 2003; Ojo \& Sadiq, 2010). However, ICCO (2017) also mentioned that extreme weather especially temperature and rainfall are important factors that will affect the optimal result. Research on the effect of the season on the cocoa beans quality was conducted by Basri (2010). This study observed the results of side grafted plants in different seasons. Based on the research result, plant species and environmental conditions (seasons) greatly affect the quality of cocoa beans, especially weight size and bean fat content. According to Mulato et al. (2009), bean size is strongly influenced by species (clones) of plants, environmental conditions (rainfall) during pod growth phase. This research was conducted to determine whether different seasons can affect the quality of cocoa beans significantly. This study was conducted to obtain information on cocoa clone responses to seasonal differences based on the characteristics of pods and beans.

\section{MATERIALS AND METHODS}

The research was carried out in two seasons: dry season (2015) and rainy season (2016) at Kaliwining Experimental Station of Indonesian Coffee and Cocoa Research Institute. Kaliwining topography is flat, in form of lowland with altitude $45 \mathrm{~m}$ asl. Climate data at Kaliwining revealed area mean maximum temperature $33^{\circ} \mathrm{C}$, average minimum temperature $21.6^{\circ} \mathrm{C}$, relative humidity average $87 \%$, and average evaporation $3.75 \mathrm{~mm}$. Soil type latosol and regosol with clay loam topsoil and clay texture subsoil. According to SchmidtFerguson classification, Kaliwining has D type with an average rainfall of $1957 \mathrm{~mm} /$ year, average dry months 4.3 months/year, and an average wet month 6.5 months/year.

This study used factorial complete design with 12 clones planted on three blocks. Three sample trees were observed from each block. The cocoa trees were planted in 2003 with a spacing of $3 \mathrm{~m} \times 3 \mathrm{~m}$. The experiment was conducted by a factorial $2 \times 12$ design arranged in a completely randomized block design and repeated in three blocks. The first factor was the season (dry and rain season). The second factor was cocoa clones (Table 1). Three random plants from each block were observed.

Observations were made on the quality characteristics of the pods and the components of cocoa pod on all the harvested pods. Observation variables included pod girth, pod length, pod weight, dry bean weight, 
Table 1. The clones used in the research

\begin{tabular}{llll}
\hline Accession number & Clone & \multicolumn{1}{c}{ Parentage } & \multicolumn{1}{c}{ Annotation } \\
\hline KW 005 & TSH 858 & Introduction from England & High production \\
KW 084 & KW 084 & Selection in Jawa Timur & High production \\
KW 094 & KEE 2 & Introduction from England & Tolerant VSD \\
KW 162 & Sulawesi 1 & Selection in Hasfarm & Tolerant VSD \\
KW 163 & Sulawesi 2 & Selection in Hasfarm & Tolerant VSD \\
KW 165 & BAL 209 & Introduction from Bah Lias & High production \\
KW 215 & KW 215 & Eksploration in Central Sulawesi & Suspected tolerant pod rot \\
KW 235 & JTC 5A & Eksploration in Jatirono & Suspected tolerant pod rot \\
KW 236 & JTC 5B & Eksploration in Jatirono & Suspected tolerant pod rot \\
KW 427 & KC 2 & Eksploration in Jatirono & Suspected tolerant pod rot \\
KW 442 & KKM 22 & Introduction from Malaysia & High production \\
KW 523 & KJ 2 & Eksploration in Jatirono & Suspected tolerant pod rot \\
\hline
\end{tabular}

pod placental weight, good bean number/ pod, number of beans/pod, number of beans/ $100 \mathrm{~g}$, bean shell content, and number of pods/tree/season.

The variability in each component of the outcome and quality was analyzed using the mean quadratic component analysis and mean square expectation of completely randomized block design using two factors. The first factor was season and the second factor was clone. Selection of clones and blocks prescribed previously recommended variety analysis using ANOVA fixed factor.

The analysis model used is as follows:

$$
\begin{aligned}
\text { Yijk }= & \mu+\alpha \mathrm{i}+\beta \mathrm{j}+\rho \mathrm{k}+(\alpha \beta) \mathrm{ij}+(\rho \alpha) \mathrm{ik} \\
& + \text { cijk } \\
\text { Yijk = } & \text { observation value on season } \mathrm{i} \text {, clone } \mathrm{j} \text {, and block } \mathrm{k} \\
\mu \quad= & \text { overall data mean } \mathrm{Y} \\
\alpha \mathrm{i} \quad= & \text { season influence to } \mathrm{i} \\
\beta \mathrm{j} \quad= & \text { clone influence to } \mathrm{j} \\
\rho \mathrm{k} \quad= & \text { block influence to } \mathrm{k} \\
(\alpha \beta) \mathrm{ij}= & \text { interaction between season to } \mathrm{i} \text { and clone to } \mathrm{j} \\
(\rho \alpha) \mathrm{ik}= & \text { block influence in season } \\
\text { cijk }= & \text { aberration }
\end{aligned}
$$

Genotype diversity, phenotypic diversity, phenotypic diversity coefficients were analyzed using the SAS program based on the analysis developed by Singh \& Chaudary (1979) which is described as follows:

Genotypic variability coefficient (CVG) and phenotypic diversity coefficient (CVF):

$$
\begin{aligned}
& C V G=\frac{\sqrt{\sigma^{2} g}}{\bar{X}} \times 100 \% \\
& C V G=\frac{\sqrt{\sigma^{2} f}}{\bar{X}} \times 100 \%
\end{aligned}
$$

$$
\begin{array}{ll}
\sigma^{2} g=\sigma^{2} \text { clone } & =\text { genotypic variant } \\
\sigma^{2} \mathrm{e} & =\text { environmental variant } \\
\sigma^{2} \mathrm{f}=\sigma^{2} \mathrm{~g}+\sigma^{2} \mathrm{e} & =\text { phenotypic variant } \\
\overline{\mathrm{X}} & =\text { general average }
\end{array}
$$

The coefficient of phenotypic diversity is categorized according to Knight (1979) which is described as follows:

- Large (CVG $>14,5 \%)$

- Medium $(5 \%<\mathrm{CVG} \leq 14,5 \%)$

- Small $(\mathrm{CVG} \leq 5 \%)$

Meanwhile, for phenotypic diversity coefficient (CVF) can be categorized according to Qosim et al. (2000) which is as follows:

- High (> 50\%)

- Medium (25\% < CVF $\leq 50 \%)$

- Low $(0<\mathrm{CVF} \leq 25 \%)$

According to Mangoendidjojo (2003), heritability states the proportion of genetic variants to the total variant (phenotype variant), which is usually expressed by percent $(\%)$. Heritability broadly written with the letter $\mathrm{H}$, therefore: 


$$
\begin{aligned}
H & =\left(\sigma^{2} \mathrm{G}\right) /\left(\sigma^{2} \mathrm{P}\right) \\
& =\left(\sigma^{2} \mathrm{G}\right) /\left(\sigma^{2} \mathrm{G}+\sigma^{2} \mathrm{E}\right)
\end{aligned}
$$

The classification of heritability values is based on Mc Whiter (1979), which is described as follows:

- $\quad$ High $\mathrm{H}>50 \%$

- $\quad$ Medium 20\% < $\mathrm{H}<50 \%$

- $\quad$ Low $\mathrm{H}<20 \%$

Stability analysis used AMMI analysis SAS 9.4 program. This model of analysis combines a variety of additives for the main effects of treatment and analysis of the major dual components with bilinear modeling for interaction effects. AMMI analysis biplot is used as a visual aid to interpret the analysis results (Gauch, 2006).

\section{RESULTS AND DISCUSSION}

In this study, the observed cocoa pods were harvested in two predetermined seasons: the rainy season (2016) and dry season (2015). Pod harvested in the dry season is pod that is formed and develops in rainy season and similar with those in dry season. Analysis result on variations for cocoa pod and bean characteristics are shown in Table 2 and Table 3. Pod and bean characteristics are presented in Table 4 and Table 5. The clones interacted differently on the formed pods. Pod length indicates significant differences in each clone (Table 2). The KEE 2 clone had longest pod length value compared to other clones, but the value was not significantly different with the TSH 858, KW 215, and
JTC 5B clones. The cocoa clone TSH 858 had a larger pod compared to other clones. Each of the cocoa clones observed also had its own characteristics and pod characteristics. Each cocoa clone had a different genetic, which affects the variability of pod morphology such as pod length, pod diameter, and other cocoa pod characters (Bekele et al., 2006).

The seasonal differences exhibited a marked effect on the pod length, and the number of pod per tree produced (Table 3 ). The characteristics of cocoa pod showed its best performance in the dry season. The cocoa pod character was affected by the distribution of rainfall that occurs six months before the pod can be harvested. Cacao pod itself can be harvested after the age of six to seven months. The high accumulation of rainfall and the availability of groundwater in that year will affect the formation of cocoa pod in the following year (Almeida \& Valle, 2007). According to Rahardjo (2011), optimal pod formation will occur at low flowering. Low flowering occurs during the dry season, as fallen flowers phenomenon occurs during this season. Photosynthesis occurs more intensively while vegetative growth is less active. As a result, there is an accumulation of asssimilate in the plant body (included in the flower stalk) which is higher than the rainy season (Prawoto, 2008).

The formation of cocoa beans is also influenced by environmental factors. Drought condition during the bean growth

Tabel 2. Analysis of variance of cocoa pod characters in dry and rainy season

\begin{tabular}{lcccccc}
\hline & & \multicolumn{5}{c}{ Middle squares } \\
\cline { 3 - 7 } Source of variation & df & Pod length & Pod girth & Pod weight & Placenta weight $\begin{array}{c}\text { Pod number/ } \\
\text { tree }\end{array}$ \\
\hline Block & 2 & 0.8 & 1.4 & 2781.0 & 10.9 & 449.6 \\
Season & 1 & $15.7 *$ & 2.0 & 19467.0 & $556.0 *$ & $5904.0 *$ \\
Block(season) & 4 & 0.8 & 1.7 & 19946.0 & 21.4 & 108.4 \\
Clone & 11 & $9.9 *$ & $15.6 *$ & $19946.0 *$ & $98.3 *$ & $288.4 *$ \\
Season*clone & 11 & 2.6 & $3.8 *$ & $10307.0 *$ & 16.9 & $192.4 *$ \\
Error & 44 & 2.9 & 1.1 & 4399.0 & 15.7 & 69.3 \\
\hline Not & & & & &
\end{tabular}


phase will usually affect bean growth itself (Delouche, 1980). During the dry season, the number of good beans/pod produced was different compared to yields in the rainy season (Table 5). The number of beans is also affected by the genotype of the plant itself. According to Prawoto (2008), a cocoa plant usually contains 20-50 cocoa beans per pod. Different clones provided high number of beans/pod. The JTC 5A clone had a higher number of good bean/pod compared to another clone (Table 4).

The number of empty beans/pods did not show any significant differences due to seasonal factors. According to Anita-Sari \&
Susilo (2013), an empty bean is bean which is not fully developed. Clonal differences showed a marked difference in the number of empty beans (Table 4). The TSH 858 clone had a fewer number of empty beans compared to other clones, indicating that the formation of beans in TSH 858 clones develops better than other clones (Table 5).

The seasonal effects on dry bean weight also had a significant effect (Table 5). In the dry season, dry bean weight show a higher value compared to dry bean weight in the rainy season. The seasonal effects on bean count did not show any significant differences (Table 5) between the dry and rainy

Table 3. Results of analysis of cocoa bean character variation in dry and rainy season

\begin{tabular}{|c|c|c|c|c|c|c|}
\hline \multirow[b]{2}{*}{ Source of variation } & \multirow[b]{2}{*}{$\mathrm{df}$} & \multicolumn{4}{|c|}{ Middle squares } & \multirow[b]{2}{*}{ Bean Count } \\
\hline & & $\begin{array}{c}\text { Good bean } \\
\text { number }\end{array}$ & $\begin{array}{l}\text { The number of } \\
\text { empty seeds }\end{array}$ & Dry bean weight & Shell levels & \\
\hline Block & 2 & 17.6 & 4.2 & 0.030 & 9.2 & 688.7 \\
\hline Season & 1 & $342.4 *$ & 4.0 & $0.090 *$ & 0.1 & 36.1 \\
\hline Block(season) & 4 & 3.4 & 0.6 & 0.005 & 0.5 & 150.5 \\
\hline Clone & 11 & $112.9 *$ & $3.7 *$ & $0.060 *$ & $9.3 *$ & $2524.0 *$ \\
\hline Season*clone & 11 & 23.8 & $3.7 *$ & $0.030 *$ & 4.2 & $713.5 *$ \\
\hline Error & 44 & 24.7 & 0.7 & 0.008 & 4.4 & 135.7 \\
\hline
\end{tabular}

Table 4. The season's influence on the cocoa pod character

\begin{tabular}{|c|c|c|c|c|}
\hline \multirow{2}{*}{ Season } & \multicolumn{4}{|c|}{ Variable average } \\
\hline & Pod length $(\mathrm{cm})$ & Pod girth $(\mathrm{cm})$ & Pod weight (g) & Pod number/tree \\
\hline Dry & $19.17 \mathrm{p}$ & $25.46^{p}$ & $474.45^{\mathrm{p}}$ & $26.71^{p}$ \\
\hline Rain & $18.23^{\mathrm{q}}$ & $25.78^{p}$ & $441.56^{p}$ & $8.65^{\text {q }}$ \\
\hline
\end{tabular}

Table 5. Bean characteristic of cocoa clones

\begin{tabular}{|c|c|c|c|c|}
\hline \multirow{2}{*}{ Clon } & \multicolumn{4}{|c|}{ Variabel average } \\
\hline & Good bean number/pod & Bean number/pod & Bean count & Bean dry weight/(g) \\
\hline TSH 858 & $40.54^{\mathrm{ab}}$ & $0.84^{\mathrm{a}}$ & $104.95^{\mathrm{ab}}$ & $0.92^{\mathrm{a}}$ \\
\hline KW 084 & $25.77^{\mathrm{d}}$ & $2.30^{\mathrm{bc}}$ & $129.22^{c}$ & $0.75^{\mathrm{b}}$ \\
\hline KEE 2 & $33.42^{\mathrm{c}}$ & $1.88^{\mathrm{abc}}$ & $132.05^{\mathrm{c}}$ & $0.74^{\mathrm{b}}$ \\
\hline Sulawesi 1 & $35.45^{\mathrm{bc}}$ & $3.34^{\mathrm{d}}$ & $98.89^{\mathrm{a}}$ & $0.83^{\mathrm{ab}}$ \\
\hline Sulawesi 2 & $31.59^{\mathrm{c}}$ & $1.78^{a b c}$ & $122.69^{c}$ & $0.79^{\mathrm{b}}$ \\
\hline BAL 209 & $37.65^{a b c}$ & $2.41^{\mathrm{cd}}$ & $105.67^{\mathrm{ab}}$ & $0.81^{\mathrm{b}}$ \\
\hline KW 215 & $35.31^{\mathrm{bc}}$ & $3.26^{\mathrm{d}}$ & $119.25^{\mathrm{bc}}$ & $0.81^{\mathrm{b}}$ \\
\hline JTC $5 \mathrm{~A}$ & $42.19^{\mathrm{a}}$ & $1.51^{\mathrm{abc}}$ & $179.56^{d}$ & $0.49^{\mathrm{c}}$ \\
\hline JTC 5B & $32.11^{\mathrm{c}}$ & $1.38^{\mathrm{abc}}$ & $118.36^{\mathrm{bc}}$ & $0.83^{a b}$ \\
\hline KC 2 & $35.95^{a b c}$ & $1.34^{\mathrm{ab}}$ & $128.47^{\mathrm{c}}$ & $0.74^{\mathrm{b}}$ \\
\hline KKM 22 & $32.66^{c}$ & $1.51^{\mathrm{abc}}$ & $121.58^{\mathrm{c}}$ & $0.76^{b}$ \\
\hline KJ 2 & $36.22^{\mathrm{abc}}$ & 1.64 abc & $129.44^{\mathrm{c}}$ & $0.73^{\mathrm{b}}$ \\
\hline
\end{tabular}


seasons. Bean size or dry bean weight is often seen in bean count, which is the number of beans in every $100 \mathrm{~g}$ (Felperlaan, 1997). As the study progress, Indonesia is experiencing El Nino and La Nina weather anomalies. El Nino delays the beginning of rainy season and extends dry season. La Nina causes hasten the beginning of rainy season and extends its duration (Suyadhi, 2016). Anomalous weather affects the formation of cocoa beans. The Sulawesi 1 clone showed the lowest bean count value, smaller/lower bean count value indicates that the bean had more weight. Bean weight is strongly influenced by plant clones, environmental conditions (rainfall) during pod development and agronomic action (Mulato et al., 2009).

The interaction between the clones and seasons on the variable number of pods (Figure 1) exhibited the clones of KKM 22, BAL 209, and KW 084 which stabilized the production of the number of pods during the rainy and dry seasons. These stable clones were demonstrated by the biplot graph where the three clones were at the center of the biplot chart. The closer to the center of the biplot graph, the more stable the performance in the related environments (Asfaw et al., 2009). Associated with the adaptability in pod formation, Sulawesi 02 (Sul 2) and KJ 2 clusters had good adaptability during the dry season compared to the rainy season, whereas TSH 858 clones were more adaptive in the rainy season. TSH 858 produced more cocoa pods in rainy season compared to the dry season. Each cocoa clone has special adaptability at its growth site, such as TSH 858 which has a good advantage in wet environments and is used as clone parent to produce suitable hybrids in wet areas (Susilo, 2011).

Based on the genotype interaction with seasons, TSH 858 clones have a stable bean count between the rainy season and the dry season (Figure 2). High-stability genotypes is characterized by not being affected by the presence or absence of stress. These are generally close to the center of biplot graph (Rashidi et al., 2013). This value indicated that bean size of TSH 858 clone was stable in each season. Other clones generally possess unstable bean count values. Some are adaptive during the rainy season and others are adaptive during the dry season. Cocoa is very sensitive to water availability. Water is a factor influencing the formation of cocoa beans closely, sufficient water in cocoa plants will deter clogging in bean filling process (Carr \& Lockwoods, 2011).

The coefficient of genetic diversity could be the basis for determining selection criteria. The estimation of heritability variables and values can be used to determine the proportion of diversity caused by environmental factors and genetic factors (AnitaSari \& Susilo, 2013).

The results of genetic variation coefficient analysis (CVG) exhibited values ranging from $0 \%-32.61 \%$ (Table 4 ). The zero value in the genetic variation coefficient is

Table 6. The season's influence on the character of cocoa beans

\begin{tabular}{lcccc}
\hline \multirow{2}{*}{ Season } & \multicolumn{4}{c}{ Variable average } \\
\cline { 2 - 5 } & Good bean number/pod & Empty bean number/pod & Bean count & Dry bean weight $(\mathrm{g})$ \\
\hline Dry & $37.07^{\mathrm{p}}$ & $1.69^{\mathrm{p}}$ & $123.48^{\mathrm{p}}$ & $0.80^{\mathrm{p}}$ \\
Rain & $32.74^{\mathrm{q}}$ & $2.17^{\mathrm{p}}$ & $124.87^{\mathrm{p}}$ & $0.73^{\mathrm{q}}$ \\
\hline Note: & The numbers followed by the same letter in the same column do not differ based on the DMRT test at a $95 \%$ \\
& confidence level. &
\end{tabular}


caused by the value of the negative genetic variant. The negative value was caused by genetic variation middle quadrant value is smaller than the middle deviation quadrant value (Allard, 1960). Zero value of genetic variation caused characteristic heritability value to be zero as well.
The coefficient of genetic variation is categorized to be high when CVG> $14.5 \%$, moderate 5\% CVG $£ 14.5 \%$, and low CVG $£ 5 \%$ (Knight, 1979). High genetic variation coefficient is exhibited in placental weight character and number of pod/tree $(32,61 \%$ and $22,63 \%)$. The other characters exhibit

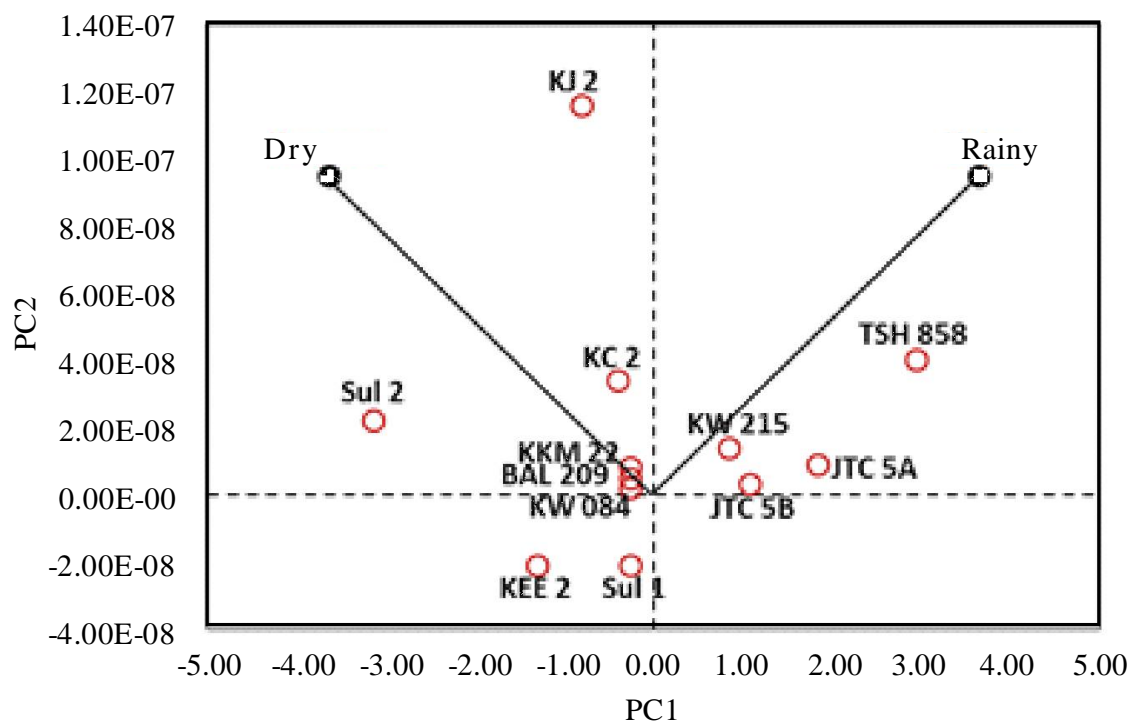

Figure 1. AMMI biplot number of pods per tree

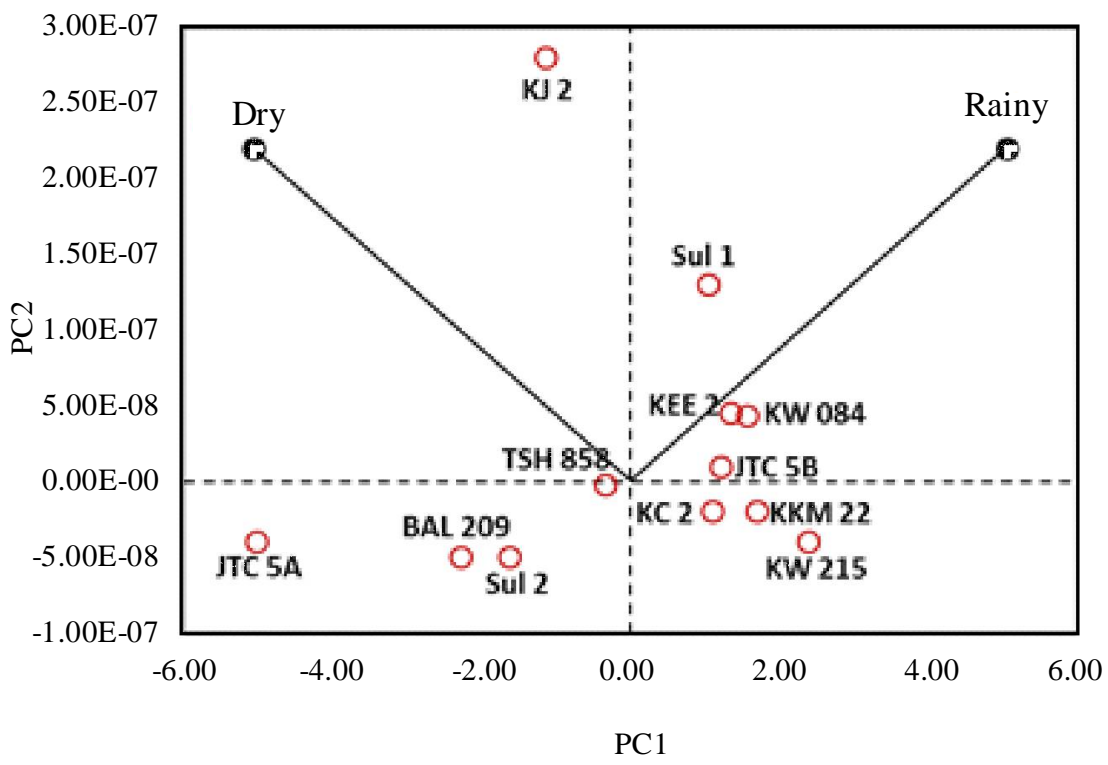

Figure 2. AMMI biplot of bean count 
Tabel 7. The coefficient of phenotypic diversity, genotype diversity coefficient, and the expected heritability of the yield component on cocoa

\begin{tabular}{lccc}
\hline Yield component & CVF, $\%$ & CVG, \% & H, \% \\
\hline Pod length & 11.07 & 5.85 & 27.90 \\
Pod girth & 7.79 & 5.52 & 50.15 \\
Pod weight & 19.73 & 8.75 & 19.68 \\
Placenta weight & 59.21 & 32.61 & 30.34 \\
Number of pods/tree & 95.56 & 22.63 & 5.60 \\
Number of good beans & 19.70 & 11.04 & 31.37 \\
Number of empty beans & 70.21 & 0 & 0 \\
Dry bean weight & 0.55 & 0.27 & 24.25 \\
Shell content & 20.29 & 8.23 & 16.45 \\
Bean Count & 20.44 & 14.20 & 48.31 \\
\hline Note: CVF =coefficient of phenotypic variation; CVG $=$ coefficient of genotypic variation; H heritability estimated
\end{tabular}

moderate. According to Martono (2009) in Rachmawati et al. (2014), plant characters with narrow variations are quantitative characters controlled by many genes (polygons). It is the end result of a growth process related to morphological and physiological properties. Low diversity will exhibit a high degree of uniformity in a population and the coefficient value of genetic variation on the physical quality character of the bean i.e bean count and dry weight of bean. The bean count character indicates the coefficient of the current genetic variation (14.20\%) and bean dry weight exhibited the coefficient of small genetic variation $(0.27 \%)$. This indicates that the physical quality of cocoa beans shows a high degree of uniformity in the twelve observed clones.

The coefficient of phenotypic variation is categorized to be high when CVF> $50 \%$, moderate $25 \%<\mathrm{CVF} £ 50 \%$, and low 0 $<$ CVF $£ 25 \%$ (Qosim et al., 2000). Some of the observed characters also showed a high coefficient of phenotypic variation, namely the number of hollow/pod, the weight of placenta, and the number of pods/trees with the values of $70.21 \%, 59.21 \%$, and $95.56 \%$. In addition to the value of the coefficient of genetic variation, heritability value is also used for selection criteria. Heritability value used in this study is a heritability value in the broad sense. Heritability value is said to be high when the value of $\mathrm{H}>50 \%$, while $20 \%<\mathrm{H}<50 \%$, and low $\mathrm{H}<20 \%$ (Mc
Whiter, 1979). The pod wrapping character has a high heritability value (Table 6) at $50.15 \%$. The alleged heritability value of a character determines selection process. The assumption of moderate to high heritability suggests that individual genetics play a major role in character appearance (Ajayi et al., 2014). Dry bean weight has low phenotypic variation coefficient $(0,55 \%)$, coefficient of low genotypic variation $(0,27 \%)$, moderate heritability value $(24,25 \%)$, and moderate direct influence $(C=-0.93)$. Based on these values, the dry weight of the beans is a crucial role in determining the number of beans $/ 100 \mathrm{~g}$.

\section{CONCLUSIONS}

Availability of water influences the clones and character of pods and beans observed. Sufficient water availability increased pod length, number of pods, number of good beans and bean dry weight. Each genetic cocoa had its own responses to environmental differences. On the observation of bean count, there was stable clones such as TSH 858. There was also clones adaptive to a particular season. On observation of the character of the number of pod, clones KKM 22, BAL 209, and KW 084 had high stability and other clones were adaptive in certain seasons. Strong plant characters influenced by genetic variation were pod length, pod wound, placenta weight, good bean count, beans dry weight and count which are exhibited from the broad 
sense heritability value classified as moderate. This value indicates that these traits can be considered for selection criteria in cocoa plant selection.

\section{REFERENCES}

Ajayi, A.T.; M.O. Adekola; B.H. Taiwo \& V.O. Azuh (2014). Character expression and differences in yield potential of ten genotypes of cowpea (Vigna unguiculata $\mathrm{L}$. Walp). International Journal of Plant Research, 4, 63-71.

Allard, R.W. (1960). Principles of Plant Breeding. John Willey \& Sons Inc., New York.

Anita-Sari, I. \& A.W. Susilo (2013). Pengembangan kriteria seleksi karakter berat biji pada tanaman kakao (Theobroma cacao L.) melalui pendekatan analisis sidik lintas. Pelita Perkebunan, 29, 174-181.

Anita-Sari, I. \& A.W. Susilo (2013). Stabilitas karakter pembungaan, pertunasan, dan potensi jumlah buah pada 21 klon kakao harapan koleksi Puslitkoka. Pelita Perkebunan, 29, 82-92.

Asfaw, A.; F. Alemayehu; F. Gurum \& M. Atnaf (2009). AMMI and SREG GGE biplot analysis for matching varieties onto soybean production environments in ethiopia. Scientific Research and Essay, 4, 1322-1330.

Assesment of Capacities Projects and Scenarios (2016). Skenario Dampak El Nino/La Nina di Indonesia. ACAPS. Jakarta, Indonesia.

Basri, Z. (2010). Mutu biji kakao hasil sambung samping. Media Litbang Sulteng, 3, 112-118.

Bekele, F.L.; I. Bekele; D.R. Butler \& G.G. Bidaisee (2006). Patterns of morphological variation in a sample of cacao (Theobroma cacao $\mathrm{L}$.) germplasm from the International Cocoa Genebank, Trinidad. Genetic Resources and Crop Evolution, 53, 933-948.

Carr, M.K.V. \& G. Lockwoods (2011). The water relations and irrigation requirements of cocoa (Theobroma cacao L.) : A Review. Experimental Agriculture, 47, 653-676.
Delouche, J.C. (1980). Environmental effects on bean development and bean quality. Horticultura Science, 15, 775-780.

Ditjenbun (2017). Statistik Perkebunan Indonesia 2016-2018. Direktorat Jenderal Perkebunan. Jakarta.

Gauch, H.G. (2006). Statistical analysis of yield trials by AMMI and GGE. Crop Science, 46, 1488-1500.

ICCO (2017). Quarterly Bulletin of Cocoa Statistics. International Cocoa Organization. Abidjan, Côte d'lvoice.

Knight, R. (1979). Quantitative genetics statistics and plant breeding. In: R. Knight (Ed.) Plant Breeding. Brisbane, Australia.

Mangoendidjojo, W. (2003). Dasar-Dasar Pemuliaan Tanaman. Kanisius. Yogyakarta.

Mc.Whiter, R.S. (1979). Breeding of Cross Pollination Crop. In: R. Knight (Ed.) Plant Breeding. Brisbane, Australia.

Mulato, S.; S. Widyotomo; Misnawi \& E. Suharyanto (2009). Petunjuk Teknis Pengolahan Produk Primer dan Sekunder Kakao. Pusat Penelitian Kopi dan Kakao Indonesia. Jember.

Ojo, A.D. \& I. Sadiq (2010). Effect of climate change on cocoa yield: a case of cocoa research institute (CRIN) farm, Oluyole local government Ibadan Oyo State. Journal of Sustainable Development in Africa, 12, 351-358.

Prawoto, A.A. (2008). Panduan Lengkap Kakao. (Editor: T. Wahyudi, T.R. Panggabean \& Pujiyanto). Penebar Swadaya. Jakarta.

Rachmawati, R.Y.; Kuswanto \& S.L. Purnamaningsih (2014). Uji keseragaman dan analisis sidik lintas antara karakter agronomis dengan hasil pada tujuh genotip padi hibrida Japonica. Jurnal Produksi Tanaman, 2, 292-300.

Rahardjo, P. (2011). Menghasilkan Benih dan Bibit Kakao Unggul. Penebar Swadaya. Jakarta.

Rashidi, M.; E. Farshadfar \& M.M. Jowkar (2013). AMMI analysis of phenotypic 
stability in chickpea genotypes over stress and non-stress environments. International Journal of Agriculture and Crop Sciences, 5, 253-260.

Singh, R.K. \& B.D. Chaudary (1979). Biometrical Methods in Quantitative Genetics Analysis. Kalyani Publisher. New Delhi.

Suyadhi (2016). Karakteristik awal dan panjang musim hujan di Indonesia. Prosiding Pertemuan Ilmiah XXX HFI Jateng dan DIY. Salatiga.
Susilo, A.W. (2011). Analisis stabilitas dayahasil beberapa hibrida unggul harapan kakao (Theobroma cacao L.) pada lokasi tumbuh berbeda. Pelita Perkebunan, 27, 168-180.

Wahyudi, T. \& P. Rahardjo (2008). Panduan Lengkap Kakao. In: T. Wahyudi, T.R. Panggabean \& Pujiyanto (Eds.). Penebar Swadaya, Jakarta.

$$
* * 0 * *
$$

